\title{
Retraction Note: Long non-coding RNA LINC00968 attenuates drug resistance of breast cancer cells through inhibiting the Wnt $2 / \beta$ - catenin signaling pathway by regulating WNT2
}

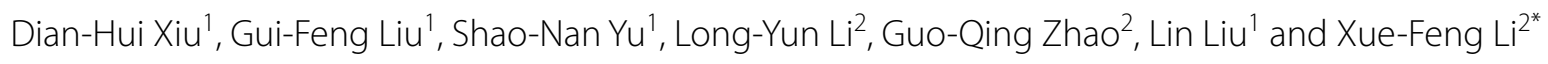

Retraction Note: J Exp Clin Cancer Res 38, 94 (2019)

https://doi.org/10.1186/s13046-019-1100-8

The Editor-in-Chief has retracted this article. After publication concerns were raised with respect to the reliability of the western blot data presented. The authors were unable to provide the raw data for this study upon request. The Editor-in-Chief therefore no longer has confidence in the integrity of the data in this article.

Xue-Feng Li has not explicitly stated whether they agree with this retraction. Gui-Feng Liu, Shao-Nan Yu, Long-Yun Li and Lin Liu have not responded to any correspondence from the Editor-in-Chief or Publisher about this retraction. Dian-Hui Xiu and Guo-Qing Zhao agree to this retraction.

\section{Author details}

'Department of Radiology, China-Japan Union Hospital of Jilin University, Changchun 130033, People's Republic of China. ${ }^{2}$ Department of Anesthesiology, China-Japan Union Hospital of Jilin University, No. 126, Xiantai Street, Changchun 130033, Jilin Province, People's Republic of China.

Published online: 27 October 2021

The original article can be found online at https://doi.org/10.1186/s13046019-1100-8.

\footnotetext{
*Correspondence: Lixfbility@163.com

${ }^{2}$ Department of Anesthesiology, China-Japan Union Hospital of Jilin

University, No. 126, Xiantai Street, Changchun 130033, Jilin Province, People's Republic of China

Full list of author information is available at the end of the article
}

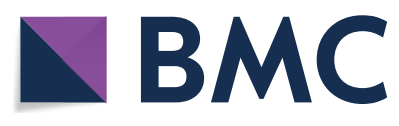

The Author(s) 2021. Open Access This article is licensed under a Creative Commons Attribution 4.0 International License, which permits use, sharing, adaptation, distribution and reproduction in any medium or format, as long as you give appropriate credit to the original author(s) and the source, provide a link to the Creative Commons licence, and indicate if changes were made. The images or other third party material in this article are included in the article's Creative Commons licence, unless indicated otherwise in a credit line to the material. If material is not included in the article's Creative Commons licence and your intended use is not permitted by statutory regulation or exceeds the permitted use, you will need to obtain permission directly from the copyright holder. To view a copy of this licence, visit http://creativecommons.org/licenses/by/4.0/. The Creative Commons Public Domain Dedication waiver (http://creativeco mmons.org/publicdomain/zero/1.0/) applies to the data made available in this article, unless otherwise stated in a credit line to the data. 